\title{
Connection Visual Style of Artwork with Habitus and the Esthetic Flavor (A Case Study of Beber Drawing by Soegeng Toekio)
}

\author{
Satriana Didiek Isnanta \\ The Fine Art Departement, The Indonesian Institute of Arts in Surakarta, \\ Jl. K.H. Dewantara 19 Surakarta, Central Java, Indonesia
}

\begin{abstract}
This article discusses the relationship between the visual style of a work of art and the habitus and aesthetic flavor of its creator with a detailed case study by Soegeng Toekio. The theory used is Bourdieu's theory of habitus and distinction. Habitus is a mental or cognitive structure with which people relate to the social world. This theory is used to determine the habitus of Soegeng Toekio having to trace the process of individual transplantation (processes of inculcations) from his childhood to adulthood. The focus of this research is on Soegeng Toekio as a child in the realm of the family, while studying at ITB and while working at the ASKI Surakarta Art Workshop (BKSR). This focus was chosen because it is very important, Soegeng Toekio, who studied art formally at FSRD ITB Bandung with the ideology of western art, but his paintings have traditional nuances. This research uses qualitative methods with descriptive design and qualitative analysis methods, which are presented descriptively with a descriptive-analytic approach. Data analysis activities as disclosed include three elements, namely data reduction, data presentation, and conclusion drawing. The result of this research is that Soegeng Toekio's beber picture characters are formed from the habitus of Soegeng Toekio since he was in the first grade at the People's School while living with his grandmother who forced him to watch the wayang wong performance at the Sri Murni building in the Kesambi area of Bandung. From there he got to know Javanese cultural arts, especially wayang wong until he worked at the Fine Arts Workshop (BKSR).
\end{abstract}

Keywords: soegeng toekio, visual style, habitus, esthetic flavor

DOI: $10.7176 / \mathrm{ADS} / 87-03$

Publication date: November $30^{\text {th }} 2020$

\section{Introduction}

Every social group (society) has a value that is believed to be its essence and existence. The essence and existence of these values ultimately form universal symbols that can be adopted by individuals, including artists, to communicate. The emergence of freedom of thought and the development of rationality gave rise to differences in the values possessed by each person or artist, including artistic values. The development of a person's artistic value is obtained from the educational process, not growing in the person of each person. This is why the value of art is rooted in certain socio-cultural contexts. (Jakob Sumardjo, 2000; 187)

In communicating the value of art, an artist puts his ideas into the form of works of art so that they can be accepted by others. Of course, the values offered by an artist cannot be separated from their socio-culture. This is closely related to human nature itself, namely as an individual and social being. Thus, the idioms, signs, symbols he chooses are related to the environment around life. One example is the painter Soegeng Toekio.

Soegeng Toekio is a painter who has been active since the 1980s. Initially, Soegeng Toekio made wayang beber paintings according to his standard on cloth and glass, which has continued to develop until now. His painting style has now been invented since 2002. His paintings are unique, decorative styles such as the simplified wayang beber painting style with a free theme (not bound by the wayang beber standard), which departs from Javanese cultural treasures, both in the form of verbal and non-verbal sources such as historical, myths, legends, puppets, folk tales, and also various ancient relics.

Soegeng Toekio moved to Solo in 1979. At that time he was accepted as an employee of the ASKI (Surakarta Karawitan Art Academy) to form the Fine Arts Workshop (BKSR) as the forerunner to the establishment of the Indonesian Art Institute (ISI) Surakarta. In the 1980s at the BKSR, Soegeng Toekio got to know wayang beber and actively developed it through painting wayang beber on the glass.

Soegeng Toekio's role in developing wayang beber painting was very large. He is the head of the BKSR, which makes program planning as well as the coordinator of the implementation. Soegeng Toekio was able to implement ASKI's vision and mission which was more traditional. Therefore, the program being implemented at that time was the development of traditional art, namely as a keris creation laboratory (tosan aji), pottery, gamelan, carvings, and glass painting.

All BKSR employees must learn the traditions according to their cultural backgrounds and artistic interests. For example, IGP Sugandhi and Aboe Bakar, who had a background in western modern painting, learned to paint the glass wayang beber, or Bagyo Suharyono who worked on keris. At that time, glass painting in Solo 
became a trend. Not only BKSR employees but also painters outside BKSR have created an association of glass painting lovers.

Understanding Soegeng Toekio's paintings certainly cannot be separated from Soegeng Toekio's social environment which shaped his habitus and aesthetic taste. Why did Soegeng Toekio's aesthetic taste prefer the style and technique of sungging in wayang beber as the expression language for his drawing? This is important to study to determine genetic factors (the background of the creation of the work which is very much influenced by the background of the artist). What are the things that influence him so that the theme and visual style of his work is like that? His focus was on the field where Soegeng Toekio got to know wayang beber and developed his painting, namely at the Artwork Workshop (BKSR) at ASKI which later developed into ISI Surakarta.

\subsection{Literature Review}

M. Choidir, "Visual Image Study by Soegeng Toekio 2011-2012", in the Journal of Brikolase Vol. 5 No. December 2, 2013. In this article, he discusses the strategy of creating Soegeng Toekio's works which he calls "Beber Pictures" and reviews some of Soegeng Toekio's works from 2011-2012. At first glance, this article is indeed similar to what will be done in later research. The thing that distinguishes this article from the research that will be carried out is that there is no background why Soegeng Toekio painted in the beber wayang style which in this study was included in the first formula. The second difference is that no review discusses the audience's response or the emotional impact of the audience to Soegeng Toekio's work. The third difference is the year boundary. In the article, M. Choidir explains that he has limited his discussion to Soegeng Toekio's 2011-2012 work, while in this research the year limit is 2000-2015. The year limitation in this study is based on research that wants to know about the process of changing Soegeng Toekio's visual style. From the description above, it can be concluded that even though the research object is almost the same, the theoretical basis used is different and the objectives of this study are different, so it can be ascertained that the research results will also be different.

Ardus M Sawega, "Four Teachers Reveal Destiny", in the catalog of the exhibition "Catur Gatra" at Balai Soedjatmoko Surakarta, 1-5 December 2012. This article is an introduction to the exhibition catalog of four artists from Surakarta, namely Arfial Arsad Hakim, Rusmadi, Sunarto, and Soegeng Toekio. Apart from discussing the theme of the exhibition, Ardus also discussed the works of artists involved in the exhibition, one of which was Soegeng Toekio. Ardus explained that Soegeng Toekio chose a traditional art style, which departs from the aesthetic values of the old culture as we find in the beber wayang, with the theme of folklore, legend, myth, and so on. Ardus's writing which alludes to Soegeng Toekio's work is indeed only brief, that is, it relates to the style of his work which is more towards tradition, especially the beber wayang. Of course, Ardus's writing is still simple and needs to be deepened, one of which is by doing research.

Vicharius DJ, "The Collaboration of Four Solo Artists on One Stage", 2015. This article is news on online media, satulingkar.com. This article reviews the exhibition in general and the works on display, including Soegeng Toekio's work. Vicarious DJ stated that Soegeng Toekio's paintings depart from themes that have become myths, folk tales, legends, and religions in society. For example, through paintings entitled Boyong Kedaton, Bersih Desa, Pisowanan, Nitibeksan, and Palagan. These five paintings intend to tell a story or ceremony that many people participated in at one time. The human figure of the ceremony in Javanese traditional costumes is depicted as a caricature and has flat decorative features. The discussion of Soegeng Toekio's works in this article is only limited to the visuals of his work and is not in-depth. Therefore, this article is very different from the research conducted. The closeness of this article with research conducted only on the aesthetic aspects of Soegeng Toekio's work as objective information.

Sri Warso Wahono, "Painting in Solo and 4 Sekawan 2015", in the exhibition catalog. "Solo 4 (Sekawan)" at Taman Ismail Marzuki Jakarta, 6-20 January 2015. At the beginning of Sri Warso Wahono's writing, he discussed the theme of the exhibition and in the following paragraph discusses the works of the artist one by one, including Soegeng Toekio's. Sri Warso Wahono stated that Soegeng Toekio's paintings departed from themes that had become myths, legends, folk tales, and religions in society. Soegeng Toekio's work is narrative, there are elements and story content behind its visual form. Human figures are depicted in caricature and decorative features. Soegeng Toekio's work can also be seen in its traces of the strength of the beber wayang traditional art. In this context, Soegeng Toekio is not autonomous in cultivating his art, but some influences serve as references to the aesthetic and artistic essence of his works. Sri Warso Wahono's article focuses more on an interpretive analysis of Soegeng Tokio's work and a few assumptions about the influence of traditional arts, particularly the beber wayang on Soegeng Toekio's work. This has actually been deepened in research on the genetic aspect, namely the background to the creation of Soegeng Toekio's work.

A work of art is a product of a social process, therefore understanding a work of art is not only limited to the field of aesthetic study (formal), but also includes other fields of art studies, namely the social field of art (art world). This field of art studies links the relationship between various parties in a large series of art. This is quite important to study because after all the artwork and the artist cannot stand alone. Especially if the artwork is 
exhibited, it cannot be separated from other values. In short, the notion of the art world is a kind of network of social organizations that support and participate in "production, distribution, and consumption. (Art world, Becker in Asmudjo J. Irianto, 2000: 88).

Every work of art has its own social art field which does not rule out the possibility of intersecting with other social art fields. For example, the paintings in Pujasari have a different social art field from Affandi's paintings. Individuals who enter the social field of Pujasari Painting art, consider that the paintings in Pujasari are works of art that are not necessarily recognized as works of art by individuals who are included in the social field of Affandi's art. Differences in perceptions or assumptions about a product are considered works of art or are not very much determined by the aesthetic tastes (art) of the actors in the social field of art.

Taste, according to Bourdieu (1994: 99) has two inseparable sides. He perceives a double meaning which forms the basis for further understanding. On the one hand, first, the taste is an ability to measure "aesthetic values" directly and intuitively. On the other hand, and this is inseparable from the former, the taste can also mean the capacity to judge the taste (flavor) of food implying a choice of some of them. From this first source of understanding, Bourdieu (1994: 170) then explains taste as the capacity to distinguish and appreciate classified practices and works (products).

As long as the action takes place in the social sphere, aesthetic decisions, for example, certainly carry importance, even though that interest is as far as symbolic interests. Because, according to Bourdieu, what is symbolic, in the context of the realm of class struggle and power, is very strategic because it has the power to legitimize domination. Therefore, symbolic distinctions - for example, artistic taste - need to be constructed. (Polity in Bourdieu, 1998: 75-86).

Aesthetic tastes are not as pure as Kant assumed. Because taste is something that is socially constructed in a concrete historical space. What deserves to be read, seen, appreciated does not refer to the rationality of pure taste, in the sense that it is without interest, empty of concept, and initial-goal, but is the result of tensions and struggles in art relations and the strategy of power to monopolize art appreciation. (Bourdieu in Martini, 2003: 19-33).

On the other hand, the taste cannot be separated from the habitus and realm where the agent (individual) is and what social position is. Habitus is the "mental or cognitive structure" by which people relate to the social world. (Rirzer \& Goodman, 2010: 581). Pierre Bourdieu defines habitus as the conditioning associated with the conditions for the existence of a class. According to him, disposition systems are time-resistant and can be inherited, the structures that are formed, which will then function as structures that form are the result of a habitus.

Bourdieu (Ritzer and Goodman, 2010: 582-590) viewed the field as relational rather than structurally. The realm is a network of relations between the objective positions in it (Bourdieu and Waquant, 1992: 97; Ritzer and Goodman. 2010: 582). The existence of these relations is separate from the consciousness and will of the individual. The domain is: (1) the arena of power as a struggle for resources or capital and also to gain certain access close to the power hierarchy; (2) a kind of relationship that is structured and unconsciously regulates the positions of individuals and groups in a society that is formed spontaneously.

The realm is a kind of competitive market in which various types of capital (economic, cultural, social, symbolic) are used and utilized. Bourdieu stated that there are three steps in the process of analyzing the realm, namely: first, describing the primacy of the domain (environment) of power (politics) to find the relationship of each specific environment with the political environment; second, describe the objective structure of the relationship between various positions in a particular domain; (3) and the analysis should try to determine the habitual characteristics of agents who occupy different types of positions in the realm. The position of agents is determined by the amount and relative weight of their own capital. Bourdieu discusses four kinds of capital, namely: economic, cultural (legal knowledge), social (valuable relationships between individuals), and symbolic of one's honor and prestige. (Ritzer and Goodman, 2012: 583-584)

\subsection{Research Method}

This study used qualitative research methods. The qualitative research design format consists of three models, namely the descriptive format, the verification format, and the grounded research format. In this study, a qualitative method with a descriptive design will be used, namely research that provides an accurate description of a particular individual or group about the conditions and symptoms that occur (Koentjaraningrat, 1993: 89). Using qualitative analysis methods, which are presented descriptively with a descriptive-analytic approach, namely qualitative methods to obtain in-depth and meaningful data. (Sugiyono, 2012: 3)

Sources of data used in this study: first is Soegeng Toekio as an artist/creator of art as a source of genetic information in the form of the background of the birth of the work and the process of his creation. Second, is the painting by Soegeng Toekio in the medium of glass, cloth, or canvas.

The third data source sources, namely observers as a source of affective information. The target sources are people who are considered to know and understand the information by the problem being studied. To select 
sources in this study was determined by a purposive sampling technique (Goetz, J.P, and Le Comte, MD. 1984). This is intended to trace sources who can be accurately asked for information.

The analysis used in this study uses an interaction analysis model. Activities in data analysis in qualitative research are carried out interactively and continue to completion so that the data is saturated. Data analysis activities as disclosed include three elements, namely data reduction, data presentation, and conclusion drawing.

\subsubsection{Discussion}

Evaluating a work of painting, there are many problems related to the advantages and disadvantages that can be revealed, such as problems with ideas, concepts, forms, media, and techniques. Fine art is indirectly a scientific area that is full of creative ideas supported by practical abilities in composing or creating aesthetic visualizations that are influenced by feelings, psychologically, or by the artist's environment. Apart from this, art is also a miniature of a big reality, as the opinion of Erich Kahler, quoted by Humar Sahman, said that:

"Art is also a human activity that explores and hereby creates new realities in a way that is beyond reason and based on sight and presents that reality symbolically or figuratively as a small world roundness that reflects the roundness of the big world.".(Sahman, 1993: 16)

The skill and ability to produce new realities will be more interesting and appreciative when supported by the presence of characters in the artwork that is made. The appearance of a character in a work usually begins with an interaction between the artist and himself, so that there is contemplation or reflection, which is related to his artistic concept, namely about what, why, how, and for what purpose he creates art. The information above is by the most important part of Herbert Mead's view, about "self-interaction".

"The internal conversation 'which a person has with himself is an essential part of Mead's view because it is a means by which humans consider and organize themselves to act. Self-interaction is also the basis for role-playing, which is at the heart of the conception of human action ". (Herbert Mead in Zamroni, 1992: 60)

The appearance of characters in works of art will become more meaningful and develop again if there is some kind of interaction with the social community so that there is a relationship between the artist, the work of art, and the community as their observers or appreciators. Therefore, understanding Soegeng Toekio's work cannot be separated from his life background, namely how Soegeng Toekio's personality was formed and the influence of the environment in which he formed Soegeng Toekio's habit and aesthetic taste.

Habitus that exists at a certain time is the result of a collective life creation that lasts for a relatively long historical period. A process of transplanting individuals (processes of inculcations), starting from childhood, which then becomes a kind of "second sense" (second sense) or the second nature of nature (second nature). Habitus produces, and is produced by social life. And it is an action which mediates between habitus and social life. According to Bourdieu, habitus is merely "proposing" what people should think and what they should choose to do (Ritzer, 2003: 523-524).

Therefore, to find out the habitus of Soegeng Toekio, he must trace the individual transplantation process (processes of inculcations) from a child to an adult. The focus of this research is on Soegeng Toekio as a child in the realm of the family, while studying at ITB and while working at the ASKI Surakarta Art Workshop (BKSR). This focus was chosen because it is very important, Soegeng Toekio, who studied art formally at FSRD ITB Bandung with the ideology of western art but his paintings have traditional nuances.

\subsubsection{Habitus and Aesthetic Taste of Soegeng Toekio}

Soegeng Toekio was born in Bandung, December 5, 1942. Born into a Javanese family and 11 siblings, his father was named Sardjoe Martoatmodjo and his mother was named Tasmi Amatangsar. Since childhood, Soegeng Toekio lived in two cultures, in his family he knew Javanese culture and outside the home, he knew Sundanese culture.

"The values that apply in my family are Javanese culture. If the mother is angry, she always uses Javanese, but the children answer in Sundanese. (Interview with Soegeng Toekio, 11 July 2016)

While attending a public school, between grade one and grade three, Soegeng Toekio lived with his grandmother and grandfather, R. Martotaruno in the Cibunut area of Bandung. From them, Sogeng Toekio got to know Javanese traditional art by watching a puppet show at the Sri Murni building located in the Kosambi area of Bandung. The show is always packed with audiences, especially the Javanese community in Bandung and its surroundings.

"Mbah Marto always invites me to see wayang orang in the Sri Murni building. Every Saturday night and on holidays, I was always invited to see wayang orang. Every time I see the show, I prefer to see my simbah sometimes laughing, smiling, or looking sad. I don't understand the point of the show, so usually in the middle of a show, it's already sleeping. It's just that, what attracted me at that time was the beautiful costumes of the players". (Interview with Soegeng Toekio, 11 July 2016).

The memory of living with his grandmother has influenced Soegeng Toekio personally. Apart from seeing 
the puppet show, little Soegeng Toekio was also introduced to Javanese cultural practices and traditions, such asmitoni, siraman atau bancaan.

"In the past, Marto Putri Rewang often asked me to do it. Have been in a procession mitoni ${ }^{l}$, see people making a wayang picture on a yellow coconut, or midodareni ${ }^{2}$ see coconut made decoration". (Interview with Soegeng Toekio, 11 July 2016).

How he was introduced to the world of performing arts and Javanese cultural traditions. This fostered curiosity to understand it and this experience would continue to carry over into adulthood.

He was acquainted with the world of art when Soegeng Toekio attended SMP Nasional, a private school equivalent to a public school. He started to like drawing because he was motivated by his drawing teacher who was an artist. Especially when the ability to draw is useful or used by the school to become a decoration in school wallboards. Finally, Soegeng Toekio became the manager of the school wall magazine and made many vignettes for wall magazine. This continued into high school. At high school, Sogeng Toekio had become an illustrator for the Pikiran Rakyat newspaper.

Furthermore, Sogeng Toekio took formal art studies at ITB by taking the field of Fine Arts Communication (equivalent to Art Education). In 1973, there was a change in governance at ITB, then there were study programs that were closed and opened, and there was a change in the name of the existing study programs. The Fine Arts Department changed its name to the Department of Fine Arts which covers the fields of study of Painting, Ceramic Art, Sculpture, Graphic Arts, Interior Design (change from Interior Architecture), Industrial Product Design, Graphic Design, and Textile Design. The Fine Arts Communication Study Program where Soegeng Toekio studied was closed, finally, he moved to the Product Design study program and graduated as a design bachelor in 1974

After graduating, Soegeng Toekio continued his student activities, working in the fields of illustration, textiles, and interiors in Jakarta. Even in the mid-1970s, Soegeng Toekio set up his own furniture workshop and had 17 employees (builders). Until finally in late 1978, SD Humardani came to Soegeng Toekio who asked him to help establish an art education in Solo.

"For seven hours we discussed art, fine arts, performing arts, and traditional art direction. Mr. Gendon was very enthusiastic, and finally, the discussion resulted in an understanding of the need for a scientific partnership between performing arts and fine arts." (Interview with Soegeng Toekio, 11 July 2016).

Soegeng Toekio moved to Solo in 1979, after being accepted as an employee of the ASKI (Surakarta Karawitan Academy of Arts) to form the Fine Arts Workshop (BKSR) as the forerunner to the establishment of the Indonesian Arts College (STSI) Surakarta and now the Indonesian Art Institute (ISI) Surakarta. BKSR was formed to prepare the development of ASKI into STSI, so other art majors are needed, not only musicality but other performing arts, especially other types of art, namely fine arts.

"In the 1978s Mr. Gendhon (Humardani) was looking for people, who would want to work and work at BKSR. At that time, those who were interested and entered were Bandi, Daliman, Yanto, Yantono, and several other people, including Pak Soegeng Toekio, if I'm not mistaken for HB Soetopo's suggestion ". (interview with Suprapto Suryadarmo, 27 January 2016)

Initially, BKSR only made keris. This is inseparable from the readiness of existing human resources and the interest of several ASKI officials in the keris, including Gendhon Humardani (Chair of ASKI) and Suprapto Suryadarmo (ASKI Secretary).

'Incidentally, Mr. Gendhon and I like and are interested in keris, and indeed at that time, there was already an activity to bring the taste of tosan aji. First, there are activities and second, there are people, " (interview with Suprapto Suryadarmo, 27 January 2016)

After the keris, BKSR developed other types of traditional art, namely pottery and glass painting. Especially for this glass painting art was initiated and programmed by Soegeng Toekio. As the head of BKSR, Soegeng Toekio has the power to make programs and forms of activities.

\subsubsection{Habitus Soegeng Toekio in the field of BKSR}

Pierre Bourdieu is a French sociologist, who tries to reconcile the debate on the influence of individuals into society and/or vice versa so that there is a process of internal externalization and external internalization of individuals in society. Bourdieu explains the structure of society, introducing the term agent; habitus; capital; and arena. Agents are defined as individuals in society who will eventually form a structure. Habitus is a way of perceiving the agent in seeing the things he is facing so that the habitus is how the agent sees something, then thinks about it, and continues the action he will take.

\footnotetext{
${ }^{1}$ Mitoni, is one of the Javanese cultural ritual processions related to the fetus in the mother's womb which is already seven months old. (mitoni from the word pitu or seven)

${ }^{2}$ Midodareni is a part of the preparation process for a traditional Javanese wedding. This procession is carried out in the family of the bride. Midodareni is taken from the word widodari or bidadari, which means that the bride during the wedding procession is beautiful like an angel.
} 
The domain in the sub-topic of this research is the field of BKSR, and the people in it are agents who fight for symbolic power ${ }^{1}$ and forming a social structure within that realm (BKSR). The focus is on Soegeng Toekio, how he competes for symbolic power with other agents in the realm of BKSR. Habitus and capital owned by Soegeng Toekio competed with the habitus and capital of other agents in the BKSR arena.

Bourdieu classifies capital into four, namely: (1) Economic capital, which includes the means of production (machines, land, labor), material (income and objects), and money which can be easily used for all purposes and is passed on from one generation. to the next generation; (2) Cultural capital, which includes all intellectual qualifications that can be produced through formal education or family inheritance. For example, the ability to present oneself in public, ownership of high-value cultural objects, certain knowledge and expertise from the results of education, as well as certificates (job titles); (3) Social capital, refers to the social network owned by the actor (individual or group) to other parties who have power; and (4) symbolic capital, which includes all forms of prestige, status, authority and legitimacy (Ritzer, 2009: 583-584).

Soegeng Toekio is a Javanese who lives in Bandung with a Sundanese culture. Although at home he was educated in the Javanese way, the environment also taught him to live in the Sundanese way. At a young age, grades 1-3 of the People's School have been introduced to Javanese culture by their grandmothers by seeing wayang oranges, but they know and practice art firsthand after entering junior high school.

Since junior high school, Soegeng Toekio has studied drawing with western techniques. Draws create posters, illustrations, and vignettes for wall magazines at his school. The concepts and techniques of western art that he had got stronger when he studied formally at ITB. In the field of modern Indonesian art, ITB is a university that really applies the concept of western art, so there is a term ITB is a laboratory (modern art) west. As stated by Arfial Arsad Hakim (66 years), Soegeng Toekio's younger class during his studies at ITB.

"When I was studying there and in the past, at ITB I was not introduced to traditional arts. We study western modern art. From the concept, aesthetics, and techniques of modern western painting. In fact, Soegeng Toekio was far above me, so I am sure that he also did not receive knowledge of traditional arts in college lectures. " (Interview, 11 August 2016)

Arfial Arsad Hakim's opinion was strengthened by Bonyong Munni Ardhi (66 years), a painter, a member of the New Art Movement from the Indonesian Academy of Fine Arts (ASRI) Yogyakarta.

"ITB is very western, in contrast to ASRI which still includes social issues such as the life of the small community or traditional ideals in its works. So that in the past it was very clear which painters with the Bandung view and which were the Jogja schools. It can be seen from his works. So Soegeng Toekio's work can be influenced from here (ISI Surakarta) not from Bandung ". (Interview, 30 July 2016)

The habitus of modern western artists or painters is to worship freedom of expression so that in creating their artworks it becomes subjective. His works are the result of an interpretation of something that touches him. Of course, the habitus is very difficult to accept traditional arts, but why does Soegeng Toekio seem like there is no problem. It turned out that the key was during his study at ITB, taking the Art Communication study program, not pure art.

"Soegeng at ITB took the Communication Arts program. That is if it is now equivalent to art education at IKIP. In the Communication Arts program, everything is learned from the pure things such as sculpture, painting, or graphics and applied ones such as graphic design, the rest is more pedagogical studies. Because there was a change in the study program at that time, Mr. Sogeng moved and graduated from the product design study program. Soegeng did not study fine art specifically like me". (interview with Arfial Arsad Hakim, 19 July 2016).

Even though he studied at ITB, Soegeng Toekio did not study fine art but education in applied arts and arts, so that the doctrine, ideology, and concepts of pure art were not in his subconscious. This made it easier for Sogeng Toekio's habitus when he was positioned as the head of BKSR to develop traditional art. Habitus Soegeng Toekio, although built from western art concepts, can still accept traditional art, because what is being learned is the concept of using art, not pure art, which prioritizes artistic expressions as individual and nonfunctional expressions. Traditional art in the concept of western art is craft/craft, which is a product/art object that has a function value beyond the interests of the art itself. His habit as a designer was also what prompted Soegeng Toekio to create glass painting works, which not only transferred the beber wayang image into glass painting, but he made glass painting works with his own design sketches and themes.

"Even though I am not a BKSR employee but since the first time I have been involved in BKSR. I work at PKJT (Central Java Arts Development Project), whose office is in the same building as BKSR in Sasono Mulyo. At that time, the main point was tradition. Finally, we chose glass painting as a representation of the traditional painting. So, together, Soegeng Toekio, Aboe Bakar, Bagyo Suharyano,

\footnotetext{
${ }^{1}$ Bourdieu interchangeably uses the terms "symbolic power", "symbolic violence", and "symbolic dominance" to refer to the same thing. Bourdieu defines the third meaning as "the power to determine the instrument of knowledge and the arbitrary expression of social reality but whose equality is not realized". It is in this sense that symbolic power is 'the power to change and create reality, that is, to change and create it as validly recognized and recognized' (Bourdieu: 1995; 168)
} 
and Gandhi studied glass painting. Some transfer the images of wayang beber, pawukon, or wayang kulit directly to the glass, but others are experimenting with these mediums. Paint it in an individual style but use glass painting techniques. Soegeng Toekio, is one of those people who doesn't just transfer the pictures to the glass, he has his own subject matter. Yes, his paintings are like his current paintings with the themes of folk tales, myths, legends or cultural events that surround him". (interview with Putut H Pramono, 21 July 2016)

Putut H Pramono's statement further strengthens that Soegeng Toekio's habitus is a practitioner of modern art, not a tradition. Moreover, besides making glass paintings, at the same time Soegeng Toekio also made abstract paintings using the collage technique.

"The year Soegeng Toekio worked at BKSR, I had a house contract with him. For the needs of a joint exhibition, he once made abstract works using collage techniques. Besides, the illustrations for the Darmonyata newspaper also use western techniques. Shading techniques and volume figures ". (Interview with Arfial Arsad Hakim, 11 August 2016)

Soegeng Toekio's attitude cannot be separated from the results of the power struggle in the cultural arena at BKSR. His cultural capital as a bachelor of arts (which at that time was still very rare) and the head of BKSR when he was struggling with the cultural capital of Gendon Humardani who was chairman of ASKI and PKJT became very lame. Soegeng Toekio's social capital that is close to Indonesian art figures from ITB is also meaningless with Gendon Humardani's closeness to the Cendana family where his older brother, Jono Humardani, became Suharto's personal assistant. Soegeng Toekio's symbolic and economic capital is experiencing the same thing.

In the battle arena in BKSR, Gendon Humardani was the winner, he was the symbolic power holder in that arena. Therefore, he also determines the reality of the truth. What was done and believed by Gendon Humardani, the other agents submitted and believed to him? Gendon Humardani had so much capital that it seemed as if the symbolic power he had become a doxa. ${ }^{1}$.

When the direction of BKSR was more focused on the development of the traditional art of the archipelago, other agencies agreed with it. That the truth of the breath of art is when developing traditional arts. Traditional art has become a legitimate art. Art that is valid, correct, and has the highest position in BKSR and ASKI. This was reproduced by cultural agents at that time until now, including Soegeng Toekio.

\subsubsection{Conclusions}

The character of Soegeng Toekio's works is in the style of illustrative figurative decoration, namely works of painting that use stylized depictions, with the strength of a character that is characteristic of a comical form like a beber wayang. Illustrates traditional events that are identified from the clothes of human figures which are then contrasted/contrasted with contemporary popular colors.

The character of Soegeng Toekio's painting is formed from the Soegeng Toekio habitus which was formed when he was in the first grade at the People's School while living with his grandmother who forced him to see wayang wong performances at the Sri Murni building in the Kesambi area of Bandung. From there he got to know Javanese cultural arts, especially wayang wong. What is inherent in his subconscious is the wayang wong costume and the geber / ornament on the wayang wong stage screen.

Habitus suggested Sogeng Toekio study illustration from Suyadi (Pak Raden) who has the same aesthetic taste related to Javanese cultural traditions. Furthermore, Sogeng Toekio's illustration skills continued to be forged when he became an illustrator. Habitus was the one who finally proposed Soegeng Toekio's current visual style of painting.

\section{References}

Binawan, Al. Andang L. "Habitus (?) Nyampah: A Reflection," in Basis, Number 05-06, Year 56, May-June 2007.

Bourdieu, Pierre, Distinction: A Social Critique of The Judgment of Taste. New York: Routledge and Kegan Paul Ltd, 1984.

Language and Symbolic Power, trans. from French by Gino Raymond \& Matthew Adamson, (Cambridge: Polity Press), cet. 4, 1995.

Bourdieu, Pierre and Loic J. D. Waquant, An Invitation to Reflexive Sociology, Chicago, The University if Chicago Press Ltd, 1992.

Burke, Peter, History and Social Theory, Jakarta: Yayasan Obor, 2001. Hal. 179-180.

Chapman, Laura H. Approaches to Art in Education. New York: Harcourt Brace Jovanovic, Inc. 1978. p. 44-62.

Choidir, M, "Visual Study of Beber Pictures by Soegeng Toekio 2011-2012", in the Journal of Brikolase Vol. 5 No. December 2, 2013. p. 89-100.

\footnotetext{
${ }^{1}$ Something that does not need to be questioned the truth.
} 
Dharsono, Wayang Painting, Surakarta, ISI Press, 2012.

Gie, The Liang. Philosophy of Beauty; Yogyakarta: Center for Useful Science Learning (PUBIB), 1996.

Goetz, J.P, and Le Comte, MD, Ethnography, and Qualitative Design in Educational Research. New York: Academic Press, Inc, 1984.

Jenkins, Richard, Pierre Bourdieu's Mind Reading (Translated: Nurhadi), Yogyakarta: Discourse Creation, 2004.

Kleden, Ignas. "Habitus: Faith in the Perspective of Cultural Production" in RP Andrianus Sunarko, OFM, et al. (eds.) Arise and Move Documentation of the Results of the 2005 Supreme Council of the Indonesian Catholic Church, Jakarta: Sekretariat SAGKI, 2005.

Koentjaraningrat, Community Research Methods. Jakarta, Gramedia Pustaka Utama, 1993.

Mahar, Chleen, and Richard Harker. (Habitus X Modal) + Domain = Practice: The Most Comprehensive Introduction to Pierre Bourdieu's Thought, Jogjakarta, Jalasutra, 2010.

Maleong, Lexy A. 1998, Qualitative Research Methods, Bandung: P.T. Gramedia.

Ritzer, George, and Douglas Goodman, Modern Sociological Theory (trans: Nurhadi), Jakarta, Kencana, 2003. Sociological Theory: From Classical Sociology Theory to the Recent Development of Postmodern Social Theory (Terj: Nurhadi) Yogyakarta: Discourse Creation, 2010.

Classical Sociological Theory - Post Modern Latest Edition (Translated: Nurhadi). Yogyakarta: Discourse Creation. 2012.

Sahman, Humar, Knowing the World of Fine Arts, About Art, Artwork, Creative Activities, Appreciation, Criticism and Aesthetics, IKIP Semarang Press. 1993.

Sugiyono, Qualitative Research Methods. Bandung: Alfabeta, 2009.

Understanding Qualitative Research, Bandung: Alfabeta, 2012.

Sahman, Humar. Recognizing the World of Fine Arts, About Art, Artwork, Creative Activities, Appreciation, Criticism and Aesthetics, Semarang: IKIP Semarang Press, 1993. pp119-128.

Sawega, Ardus M, "Four Teachers Reveal Destiny", in the catalog of the exhibition "Catur Gatra" at Balai Soedjatmoko Surakarta, December 1-5 2012.

Sulistyo-Basuki. Research methods. Jakarta: Wedatama Widya Sastra and Faculty of Humanities, University of Indonesia, 2006.

Sumardjo, Jakob, Philosophy of Art, Bandung, Publisher ITB, 2000.

Vicharius DJ, "The Collaboration of Four Solo Artists on One Stage, in http://satulingkar.com/detail/read/8/2790/kola borasi-four -perupa-solo-on-one-stage, 2015. downloaded 21 June 2016.

Wahono, Sri Warso, "Painting in Solo and 4 Sekawan 2015", in the catalog of the exhibition, "Solo 4 (Sekawan)" at Taman Ismail Marzuki Jakarta, 6-20 January 2015.

Zamroni. Introduction to Social Theory Development. Yogyakarta: Tiara Wacana, 1992.

\section{List of informant}

Afatara, Narsen. (66). Professor of Fine Arts, UND FSRD. Jl. Ir. Sutami No. 17a The interests of Surakarta.

Ardhi, Bonyong Munni. (70). Visual Artist. Jl. Rajawali No. 14 Perum. UNS IV Lecturer Triyagan Mojolaban Sukoharjo.

Hakim, Arfial Arsad (66), painter. Perum. Maduasri Blok A No. 3 Group of Colomadu Karanganyar.

Pramono, Putut H (60), painter and lecturer of DKV FSRD UNS. Jl. Tunggul Kawung No. 6 Perum RC Palur Karanganyar.

Suryodarmo, Suprapto (71), an artist and owner of Padepokan Lemah Putih. Desa Bonorejo RT 01 RW 02, kel. Plesungan Gondangrejo, Karanganyar.

Toekio, Soegeng (74), Painter and Dean of the Faculty of Fine Arts at USAHID Surakarta. Perum. Maduasri Blok A No. 34 Group of Colomadu Karanganyar. 